\title{
额济纳三角洲胡杨和多枝柽柳水分来源解析
}

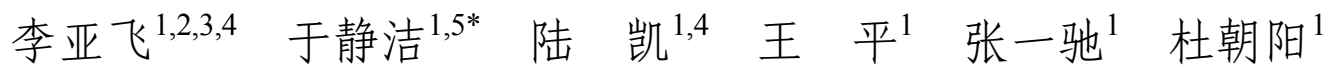 \\ ${ }^{1}$ 中国科学院地理科学与资源研究所陆地水循环及地表过程重点实验室, 北京 $100101 ;{ }^{2}$ 中国科学院大学, 北京 $100049 ;{ }^{3}$ 中国-丹麦科研教育中心, 北 \\ 京 $100190 ;{ }^{4}$ 中国科学院大学中丹学院, 北京 $100190{ }^{5}$ 中国科学院大学资源与环境学院, 北京 100190
}

摘 要 为研究黑河下游额济纳三角洲典型河岸带植物胡杨(Populus euphratica) 和多枝柽柳(Tamarix ramosissima) 的水分来 源及其时空变化特征, 于2015-2016年植物生长期在额济纳东、西河沿岸选取8处样点, 分别采集胡杨和多枝柽柳木质部、土 壤以及降水、河水、地下水样品, 分析测试获取各样品的氧稳定同位素比率 $\left(\delta^{18} \mathrm{O}\right)$, 并利用氧同位素直接对比法确定植物主要 吸水层位，利用IsoSource线性混合模型确定胡杨和多枝柽柳水分来源构成及比例。研究表明: 河水和地下水为胡杨和多枝柽 柳的主要补给水源, 降水补给因雨水少且入渗浅可忽略不计; 胡杨和多枝柽柳吸收土壤水的层位因地下水位波动、土壤物理 特性、河水对土壤水的侧向补给及漫溢补给等存在较大的空间差异，但其利用河水和地下水的比例未见明显空间差异; 胡杨 更多地利用河水 $(68 \%)$, 而多枝柽柳更多地利用地下水 $(65 \%)$; 植物水分来源对生态输水工程响应敏感, 河水贡献率在输水期 增大至 $84 \%$ 和 $48 \%$, 非输水期下降至 $63 \%$ 和 $30 \%$, 地下水贡献率在输水期下降至 $16 \%$ 和 $52 \%$, 非输水期增大至 $37 \%$ 和 $70 \%$ 。值得 指出的是，河岸带地下水与河水交互作用强烈，导致地下水与河水的 $\delta^{18} \mathrm{O}$ 较为接近，使得源分解析定量具有不确定性。

关键词 干旱区; 河岸带; 植物水分来源; 氧稳定同位素; 生态输水

引用格式: 李亚飞, 于静洁, 陆凯, 王平, 张一驰, 杜朝阳 (2017). 额济纳三角洲胡杨和多枝柽柳水分来源解析. 植物生态学报, 41, 519-528. doi: $10.17521 /$ cjpe.2016.0381

\section{Water sources of Populus euphratica and Tamarix ramosissima in Ejina Delta, the lower reaches of the Heihe River, China}

LI Ya-Fei ${ }^{1,2,3,4}$, YU Jing-Jie ${ }^{1,5^{*}}$, LU Kai ${ }^{1,4}$, WANG Ping ${ }^{1}$, ZHANG Yi-Chi ${ }^{1}$, and DU Chao-Yang ${ }^{1}$

${ }^{1}$ Key Laboratory of Water Cycle \& Related Land Surface Processes, Institute of Geographic Sciences and Natural Resources Research, Chinese Academy of Sciences, Beijing 100101, China; ${ }^{2}$ University of Chinese Academy of Sciences, Beijing 100049, China; ${ }^{3}$ Sino-Danish Center for Education and Research, Beijing 100190, China; ${ }^{4}$ Sino-Danish College, University of Chinese Academy of Sciences, Beijing 100190, China; and ${ }^{5}$ College of Resources and Environment, University of Chinese Academy of Sciences, Beijing 100190, China

\section{Abstract}

Aims We aim to evaluate the water sources of typical riparian arbor species (Populus euphratica) and shrub species (Tamarix ramosissima), and analyze the spatial and temporal dynamics of plant water source in Ejina Delta, the lower reaches of the Heihe River, China.

Methods Eight sampling sites were selected in the riparian zones along the East River and West River in Ejina. The plant xylem water, soil moisture, rainwater, stream water and groundwater were taken and pretreated during the growing season in 2015-2016, and the stable oxygen isotope ratio $\left(\delta^{18} \mathrm{O}\right)$ for each water sample was measured. The $\delta^{18} \mathrm{O}$ of plant xylem water and soil moisture were compared to estimate the dominant depth of root water uptake, and the linear-mixed model called "IsoSource" were applied to determine plant water sources and quantify their proportions.

Important findings This study indicated that the main recharge sources for $P$. euphratica and T. ramosissima were stream water and groundwater. The contributions of rain water to them was negligible due to the limited amount and the shallow infiltration depth of local rainfall. As affected by groundwater level fluctuation, soil physical properties, as well as lateral and vertical recharge of stream water on soil moisture, the dominant depth of root water uptake spatially varied. However, the relative contributions of stream water or groundwater to plant water sources did not change significantly across space. Populus euphratica used more stream water (68\%), while T. ramosissima used more groundwater (65\%). Plant water sources were sensitive to environmental flow controls. The contributions of stream water to the water sources of the two species went up to $84 \%$ and $48 \%$ for $P$.

收稿日期Received: 2016-12-12 接受日期Accepted: 2017-05-04

* 通信作者Author for correspondence (E-mail: yujj@igsnrr.ac.cn) 
euphratica and T. ramosissima respectively during the discharge period, but dropped to $63 \%$ and $30 \%$ during the non-discharge period. On the other hand, the contributions of groundwater decreased to $16 \%$ and $52 \%$ during the discharge period, but increased to $37 \%$ and $70 \%$ during non-discharge period. It is noteworthy that the high similarity of $\delta^{18} \mathrm{O}$ between stream water and groundwater due to extensive water exchange in the riparian zone made increase the uncertain in quantifying plant water sources.

Key words arid region; riparian zone; plant water source; stable oxygen isotope; environmental flow controls

Citation: Li YF, Yu JJ, Lu K, Wang P, Zhang YC, Du CY (2017). Water sources of Populus euphratica and Tamarix ramosissima in Ejina Delta, the lower reaches of the Heihe River, China. Chinese Journal of Plant Ecology, 41, 519-528. doi: 10.17521/cjpe. 2016.0381

额济纳三角洲位于中国第二大干旱内陆河黑 河流域的下游, 降水稀少, 蒸发强烈(Wang et al., 2011)。该地区的植被主要依赖于黑河上、中游下泄 来水及其补给的土壤水和地下水(Wei et al., 2012), 因此多沿河流两岸及尾问湖岸分布(朱军涛等, 2011)。自2000年实施生态输水工程以来, 额济纳三 角洲河道过水过程和地下水埋深等发生了很大变化 (司建华等, 2013; Wang et al., 2013), 该地区植被, 尤其是河岸带植被得到了恢复(张一驰等, 2011)。已 有研究表明, 生长在干旱环境中的植物能随水分条 件的变化调整其水分利用策略, 以适应干旱缺水环 境(Huxman et al., 2004)。实施生态输水工程后, 河 岸带植物如何响应水分利用? 对这一问题的科学阐 释将有助于评估和改进生态输水方案。进行额济纳 三角洲代表性植物的水分来源解析是回答这个问题 的前提。

利用氧同位素开展植物水分来源解析, 被公认 为一种有效的科研手段。学者们已利用氧同位素在 非洲干旱区(Schachtschneider \& February, 2010)、美 国西南干旱区(Ehleringer et al., 1991; Snyder \& Williams，2000) 以及中国西北干早区(巩国丽等, 2011; 邢星等, 2014)开展了植物水分来源的研究。 土壤水分被植物根系吸收并向木质部运输的过程中 不发生氧同位素分馏(Ehleringer \& Dawson, 1992), 为利用氧同位素研究植物水分来源提供了理论基 础。氧同位素亦被应用于额济纳三角洲的植物水分 来源研究(禇建民, 2007; 赵良菊等, 2008; 尹力等, 2012; 陈小丽等, 2014), 但因已有研究选取样点单 一和未进行连续采样等, 导致我们对“额济纳三角 洲生态输水对植物水分来源的影响” 问题认识不足, 亟待进行样点加密和生长期的连续采样, 为系统探 究植物对水分的利用提供科学依据。

本研究在额济纳三角洲东、西河沿岸选取 8 个 样点, 于植物生长期连续采集代表性植物胡杨
(Populus euphratica)和多枝柽柳(Tamarix ramosis$\operatorname{sima}$ )木质部、土壤以及各水源样品, 利用氧同位素 直接对比法和IsoSource线性混合模型, 研究了额济 纳三角洲胡杨和多枝柽柳的水分来源及其时空变化 规律。研究所获得的胡杨和多枝柽柳对水分的利用 以及对水源变化的响应结果, 可丰富干旱区植物水 分来源研究, 并为基于绿洲生态保护的生态输水方 案制定提供依据。

\section{1 研究区概况和研究方法}

\section{1 研究区概况}

研究区额济纳三角洲(图1)面积约 $8022 \mathrm{~km}^{2}$, 属内陆干燥气候, 年平均气温为 $9.1{ }^{\circ} \mathrm{C}$, 极端高温 为 $43.7{ }^{\circ} \mathrm{C}$, 极端低温为 $-35.3{ }^{\circ} \mathrm{C}$; 年降水量为 $34.5 \mathrm{~mm}$ (1961-2014年) (杜朝阳, 2016)。黑河经狼心山水文 站入额济纳后, 分为东、西河两大支流。据狼心山 水文站1991-2016年实测资料, 生态输水工程实施 前(1991-1999年)黑河入额济纳的径流量平均为 4.78 亿 $\mathrm{m}^{3} \cdot \mathrm{a}^{-1}$, 实施生态输水工程后(2000-2016年) 径流量增至 5.88 亿 $\mathrm{m}^{3} \cdot \mathrm{a}^{-1}$ (杜朝阳, 2016)。研究区 地下水埋深较浅, 南部为 1.0-2.0 m, 中部为 2.0-3.5 m, 北部为3.5-8.0 m (Wang et al., 2011)。 该地区植被稀疏、种群单一, 以旱生、耐盐碱的 荒漠植被为主, 绿洲主要分布于东、西河沿岸和 低洼地带, 沿河乔灌木植被主要为胡杨、多枝柽 柳等(朱军涛等, 2011)。

\section{2 采样与数据收集}

考虑到研究区东河与西河沿岸水源条件和土 壤物理特性的差异、胡杨和多枝柽柳在河岸带的分 布(朱军涛等, 2011)以及采样的便利性, 在东、西河 沿岸自上而下设置了 8 个样点(图1)。每月采样1次, 于2015年7-9月和2016年6-9月采集胡杨和多枝柽柳 木质部样品和土壤样品。其中 2015 年设置了样点 $\mathrm{E} 2 、 \mathrm{E} 3 、 \mathrm{E} 4 、 \mathrm{E} 5 、 \mathrm{E} 6,2016$ 年增设样点E1和W1、

www.plant-ecology.com 


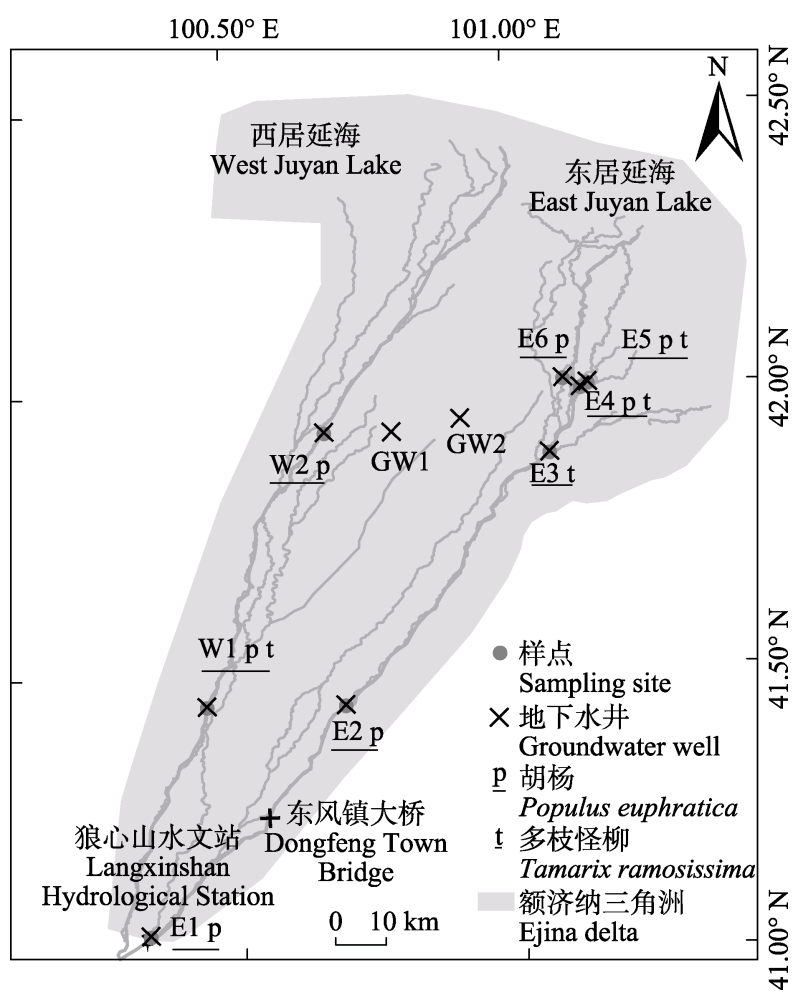

图1 研究区位置及样点。图中所标示各地点地理坐标如下: 东风镇大桥 $\left(100.55^{\circ} \mathrm{E}, 41.25^{\circ} \mathrm{N}\right), \mathrm{E} 1\left(100.33^{\circ} \mathrm{E}, 41.04^{\circ} \mathrm{N}\right)$, E2 $\left(100.69^{\circ} \mathrm{E}, 41.44^{\circ} \mathrm{N}\right)$, E3 $\left(101.07^{\circ} \mathrm{E}, 41.88^{\circ} \mathrm{N}\right)$, E4 $\left(101.12^{\circ} \mathrm{E}, 41.99^{\circ} \mathrm{N}\right), \mathrm{E} 5\left(101.14^{\circ} \mathrm{E}, 42.00^{\circ} \mathrm{N}\right), \mathrm{E} 6\left(101.09^{\circ} \mathrm{E}\right.$, $\left.42.01^{\circ} \mathrm{N}\right)$, GW1 $\left(100.79^{\circ} \mathrm{E}, 41.92^{\circ} \mathrm{N}\right)$, GW2 (100.91 ${ }^{\circ} \mathrm{E}$, $\left.41.94^{\circ} \mathrm{N}\right)$, 狼心山水文站 $\left(100.32^{\circ} \mathrm{E}, 41.04^{\circ} \mathrm{N}\right), \mathrm{W} 1\left(100.44^{\circ} \mathrm{E}\right.$, $\left.41.44^{\circ} \mathrm{N}\right), \mathrm{W} 2\left(100.67^{\circ} \mathrm{E}, 41.92^{\circ} \mathrm{N}\right)$ 。

Fig. 1 Location of the study area and sampling sites. The coordinates of the sites in the figure are as follows: Dongfeng Town Bridge $\left(100.55^{\circ} \mathrm{E}, 41.25^{\circ} \mathrm{N}\right)$, E1 $\left(100.33^{\circ} \mathrm{E}, 41.04^{\circ} \mathrm{N}\right)$, E2 $\left(100.69^{\circ} \mathrm{E}, 41.44^{\circ} \mathrm{N}\right)$, E3 $\left(101.07^{\circ} \mathrm{E}, 41.88^{\circ} \mathrm{N}\right)$, E4 $\left(101.12^{\circ}\right.$ E, $\left.41.99^{\circ} \mathrm{N}\right)$, E5 $\left(101.14^{\circ} \mathrm{E}, 42.00^{\circ} \mathrm{N}\right)$, E6 $\left(101.09^{\circ} \mathrm{E}, 42.01^{\circ} \mathrm{N}\right)$, GW1 $\left(100.79^{\circ} \mathrm{E}, 41.92^{\circ} \mathrm{N}\right)$, GW2 $\left(100.91^{\circ} \mathrm{E}, 41.94^{\circ} \mathrm{N}\right)$, Langxinshan Hydrological Station $\left(100.32^{\circ} \mathrm{E}, 41.04^{\circ} \mathrm{N}\right), \mathrm{W} 1\left(100.44^{\circ} \mathrm{E}, 41.44^{\circ} \mathrm{N}\right)$, W2 $\left(100.67^{\circ} \mathrm{E}, 41.92^{\circ} \mathrm{N}\right)$.

W2。2015年7月和2016年9月, 在输水期(即狼心山水 文站向下放水的时期，包括2015年7月6日到7月 22 日和2016年8月22日到11月16日)进行采样，其余月 份采样均在非输水期进行; 样点E3和W1因在输水 期被河水淹没，未采集到对应时段的植物和土壤 样品。

在样点附近开展土壤剖面调查并分层采集土 壤样品, 利用激光粒度仪进行土壤粒径分级; 采用 美国农业部土壤分级标准进行土壤质地分类, 结 果如表1所示。土壤质地作为分层采集土壤样品的 依据, 在现场采样时依据实时土壤含水量的变化 加密分层采样。土壤样品采集的最大深度为饱和土 壤层上边界, 采集 2 个重复样。部分较干表层的土
壤未采集。

同步采集样点内胡杨和多枝柽柳木质部样品, 采集部位为植株阳面第一个分支，在此部位截取 5 $\mathrm{cm}$ 长的木栓化枝条，去除其韧皮部，保留其木质部; 采集 4 个重复样品。土壤和植物样品采集后, 迅速装 入 $20 \mathrm{~mL}$ 螺纹玻璃瓶, 拧紧瓶盖, 并用帕拉膜密封 缝隙处, 在 $-10{ }^{\circ} \mathrm{C}$ 下冷冻保存。

同步采集浅层地下水样品, 采集位置除 8 个样 点外, 还包括距离西河 $10 \mathrm{~km}$ 的 GW1和距离东河 13 $\mathrm{km}$ 的GW2 (图1), 主要是因为样点地下水受河水影 响较大, 故将远离河道的 GW1和GW2处的地下水, 作为区域地下水本底值(不受河水干扰时的值)。降 水与河水样采集时段为2015年6月至2016年9月; 降 水样的采集位置为狼心山水文站(图1), 每场降水采 集1份样品; 沿东、西河(图1, 狼心山水文站、东风 镇大桥、E2、E3、W1、W2处河道)采集河水样, 采 样频率在输水期为每天 1 份样品, 非输水期为每 10 天1份样品。降水、河水和地下水样品采集后装入50 $\mathrm{mL}$ 塑料瓶, 拧紧瓶盖, 并用电工胶密封瓶口, 将样品 在 $4{ }^{\circ} \mathrm{C}$ 下冷藏贮存。

样点E5 (图1)处的降水量数据和各个埋深(2、4、 10、 20 和 $40 \mathrm{~cm}$ )的土壤体积含水量数据 $(2015.09 .09$ 00: 00: 00至2015.09.10 00: 00: 00, 数据采集频率为 $10 \mathrm{~min}$ 一次, 为全年最大 2 日降水量所在时段), 从黑 河计划数据管理中心获取, 用于验证研究区降水入 渗的最大土壤埋深(Liu et al., 2011; Li et al., 2013)。

\section{3 样品处理和测定}

植物木质部和土壤样品经室内低温真空抽提 (全自动真空冷凝抽提系统LI-2100, LICA United, 北京)获取植物木质部水分和土壤水, 与降水、河 水、地下水一起经过滤后, 利用液态水同位素分析 仪(LGR DLT-100, Los Gatos Research, Los Gatos, USA)分析其样品的氧稳定同位素比率 $\left(\delta^{18} \mathrm{O}\right) ; \delta^{18} \mathrm{O}$ 的测量精度为 $0.3 \%$ 。

$$
\delta_{\text {sample }}=\left[\frac{R_{\text {sample }}}{R_{\text {standard }}}-1\right] \times 1000 \quad(\% \mathrm{VSMOW})
$$

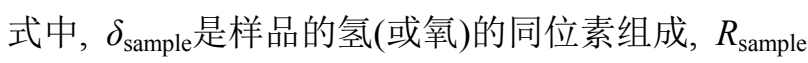
是样品中氢(或氧)的重同位素和轻同位素丰度之比 $\left({ }^{2} \mathrm{H} /{ }^{1} \mathrm{H}\right.$ 或 $\left.{ }^{18} \mathrm{O} /{ }^{16} \mathrm{O}\right), R_{\text {standard }}$ 是维也纳标准平均海水 (VSMOW)的氢(或氧)的重同位素和轻同位素丰度 之比 $\left({ }^{2} \mathrm{H} /{ }^{1} \mathrm{H}\right.$ 或 $\left.{ }^{18} \mathrm{O} /{ }^{16} \mathrm{O}\right)$, 其中 ${ }^{2} \mathrm{H} /{ }^{1} \mathrm{H}$ 值为 0.00015576 , ${ }^{18} \mathrm{O} /{ }^{16} \mathrm{O}$ 值为 0.0020052 。 
表1 各样点土壤质地剖面

Table 1 Soil textural profiles at each sampling site

\begin{tabular}{|c|c|c|c|c|c|}
\hline $\begin{array}{l}\text { 样点 } \\
\text { Sampling site }\end{array}$ & $\begin{array}{l}\text { 土壤埋深 } \\
\text { Soil depth (cm) }\end{array}$ & $\begin{array}{l}\text { 土壤质地 } \\
\text { Soil texture }\end{array}$ & $\begin{array}{l}\text { 样点 } \\
\text { Sampling site }\end{array}$ & $\begin{array}{l}\text { 土壤埋深 } \\
\text { Soil depth (cm) }\end{array}$ & $\begin{array}{l}\text { 土壤质地 } \\
\text { Soil texture }\end{array}$ \\
\hline \multirow[t]{8}{*}{ E1 } & $0-80$ & 砂土 Sand & E5 & $0-50$ & 粉壤土 Silt loam \\
\hline & $80-85$ & 壤质砂土 Loamy sand & & $50-100$ & 壤土 Loam \\
\hline & $85-90$ & 砂土 Sand & & $100-130$ & 粉壤土 Silt loam \\
\hline & $90-100$ & 细砂 Fine sand & E6 & $0-30$ & 壤质细砂 Loamy fine sand \\
\hline & $100-130$ & 砂土 Sand & & $30-90$ & 细砂 Fine sand \\
\hline & $130-170$ & 细砂 Fine sand & & $90-120$ & 砂黏土 Sandy clay \\
\hline & $170-185$ & 砂壤土 Sandy loam & & $120-160$ & 细砂 Fine sand \\
\hline & $185-200$ & 壤质砂土 Loamy sand & & $160-180$ & 壤土 Loam \\
\hline \multirow[t]{5}{*}{ E2 } & $0-20$ & 壤质细砂 Loamy fine sand & & $180-210$ & 砂土 Sand \\
\hline & $20-50$ & 细砂壤土 Fine sandy loam & & $210-230$ & 黏土 Clay \\
\hline & $50-70$ & 极细砂壤土 Very fine sandy loam & & $230-320$ & 细砂 Fine sand \\
\hline & $70-100$ & 粉壤土 Silt loam & W1 & $0-90$ & 壤质砂土 Loamy sand \\
\hline & $100-200$ & 砂土 Sand & & $90-110$ & 壤质粗砂 Loamy coarse sand \\
\hline \multirow[t]{4}{*}{ E3 } & $0-30$ & 粉壤土 Silt loam & & $110-130$ & 砂土 Sand \\
\hline & $30-80$ & 细砂壤土 Very fine sandy loam & & $130-160$ & 粗砂 Coarse sand \\
\hline & $80-105$ & 细砂 Fine sand & & $160-210$ & 砂土 Sand \\
\hline & $105-220$ & 粗砂 Coarse sand & W2 & $0-60$ & 壤质砂土 Loamy sand \\
\hline \multirow[t]{6}{*}{ E4 } & $0-15$ & 细砂壤土 Fine sandy loam & & $60-80$ & 砂土 Sand \\
\hline & $15-60$ & 砂壤土 Very fine sandy loam & & $80-120$ & 粉壤土 Silt loam \\
\hline & $60-120$ & 粉壤土 Silt loam & & $120-200$ & 砂土 Sand \\
\hline & $120-170$ & 砂土 Sand & & $200-210$ & 粗砂 Coarse sand \\
\hline & & & & $210-230$ & 壤质砂土 Loamy sand \\
\hline & & & & $230-260$ & 粗砂 Coarse sand \\
\hline
\end{tabular}

各样点地理坐标见图1。

The coordinates of each sampling site are the same as in Fig.1.

植物和土壤样品的氧稳定同位素比率 $\left(\delta^{18} \mathrm{O}\right)$ 采 用经光污染校正后的 $\delta^{18} \mathrm{O}$ 值, 校正方法与校正公式 参见孟宪菁等(2012); 降水、河水和地下水的 $\delta^{18} \mathrm{O}$ 直 接采用仪器所测 $\delta^{18} \mathrm{O}$ 值。

\section{4 数据分析方法}

利用Rstudio软件(https://www.rstudio.com/)进行 各层土壤水分 $\delta^{18} \mathrm{O}$ 的差异性分析, 若 $t$ 检验的 $p \geqslant$ 0.05 , 则认为某两层土壤水的 $\delta^{18} \mathrm{O}$ 没有差异。依据检 验结果合并相似的邻近土壤层, 取合并土壤层的 $\delta^{18} \mathrm{O}$ 平均值, 作为合并后土壤层的氧稳定同位素比 率 $\left(\delta^{18} \mathrm{O}\right)$ 值。

植物水分来源的确定采用氧同位素直接对比 法和 IsoSource 线性混合模型法 (https://www.epa. gov/eco-research/stable-isotope-mixing-models-estima ting-source-proportions)。氧同位素直接对比法用于 判定植物吸收水分的土壤层位, 其原理为: 将植物 木质部水分的 $\delta^{18} \mathrm{O}$ 值与各层土壤水的 $\delta^{18} \mathrm{O}$ 值进行比 较, 与植物木质部 $\delta^{18} \mathrm{O}$ 值较为接近的土壤层即为该 植物吸收土壤水的主要层位。IsoSource线性混合模
型用于定量各补给水源(降水、河水和地下水)对植 物水分的贡献率, 其原理为: 以土壤水为纽带, 根 据各层土壤水对植物水分的贡献率和各补给水源对 土壤水的贡献率, 得到各补给水源对植物水分的贡 献率。具体操作为: 在模型中输入各土壤层水分的 $\delta^{18} \mathrm{O}$ 值和植物木质部水分的 $\delta^{18} \mathrm{O}$ 值, 计算得到“各土 壤层对植物水分所有可能的贡献率组合”; 输入某 土壤层水分的 $\delta^{18} \mathrm{O}$ 值和各补给水源的 $\delta^{18} \mathrm{O}$ 值，计算 得到“各补给水源对某土壤层所有可能的贡献率组 合”; 二者统计平均值相乘, 得到“各补给水源对植 物水分的贡献率平均值”。模型的参数增量设为 $1 \%$, 质量平衡公差设为 $0.01 \%$ 。

\section{2 结果}

\section{1 各样品的 $\delta^{18} \mathrm{O}$}

降水的氧稳定同位素比率 $\left(\delta^{18} \mathrm{O}\right)$ 为 $-8.89 \%$ 土 5.74\% (平均值土标准误差, 下同)(图 2A), 河水的 $\delta^{18} \mathrm{O}$ 为 $-6.67 \% 0 \pm 1.03 \%$ （图2B)。地下水的 $\delta^{18} \mathrm{O}$ 为 $-6.74 \% 0 \pm 1.21 \%$ ，但具有空间差异性(表2); 其中各 

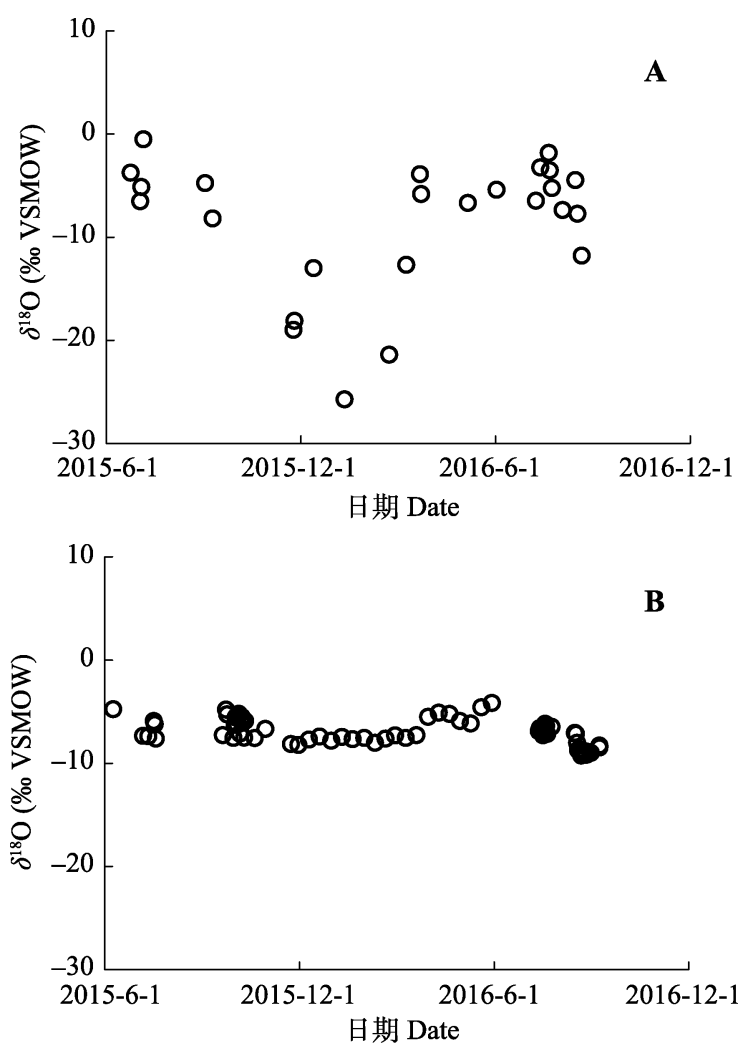

图2 研究区降水 $(\mathbf{A})$ 与河水 $(\mathbf{B})$ 的氧稳定同位素比率 $\left(\delta^{18} \mathrm{O}\right)$ 。 VSMOW, 维也纳标准平均海水。

Fig. 2 The stable oxygen isotope ratio $\left(\delta^{18} \mathrm{O}\right)$ of rainwater (A) and stream water (B) in the study area. VSMOW, Vienna standard mean ocean water.

表2 研究区地下水的氧稳定同位素比率 $\left(\delta^{18} \mathrm{O}\right)$

Table 2 The stable oxygen isotope ratio $\left(\delta^{18} \mathrm{O}\right)$ of groundwater in the study area

\begin{tabular}{lll||lll}
\hline $\begin{array}{l}\text { 日期 } \\
\text { Date }\end{array}$ & \begin{tabular}{ll|ll} 
样点 \\
Spot
\end{tabular} & $\delta^{18} \mathrm{O}(\%)$ & $\begin{array}{l}\text { 日期 } \\
\text { Date }\end{array}$ & $\begin{array}{l}\text { 样点 } \\
\text { Spot }\end{array}$ & $\delta^{18} \mathrm{O}(\%)$ \\
\hline $2016-5-31$ & E1 & -7.39 & $2015-8-16$ & E5 & -6.29 \\
$2015-7-22$ & E2 & -5.94 & $2015-9-13$ & E5 & -6.69 \\
$2015-8-16$ & E2 & -5.39 & $2015-8-16$ & E6 & -5.56 \\
$2015-9-13$ & E2 & -5.60 & $2016-5-29$ & E6 & -7.02 \\
$2016-5-31$ & E2 & -6.94 & $2015-7-21$ & E6 & -6.47 \\
$2015-8-16$ & E3 & -5.73 & $2015-9-13$ & E6 & -6.12 \\
$2015-9-13$ & E3 & -5.57 & $2016-5-31$ & GW1 & -9.84 \\
$2016-5-30$ & E3 & -6.96 & $2016-5-31$ & GW2 & -9.84 \\
$2015-7-19$ & E4 & -5.77 & $2016-5-31$ & W1 & -5.95 \\
$2015-8-16$ & E4 & -7.35 & $2016-5-31$ & W2 & -7.08 \\
$2015-9-13$ & E4 & -5.22 & & & \\
\hline
\end{tabular}

各样点地理坐标见图1。

The coordinates of each sampling site are the same as in Fig.1.

样点处地下水的 $\delta^{18} \mathrm{O}$ 为 $-6.31 \% 0 \pm 1.08 \%$, 距西河 $10 \mathrm{~km}$ 的 GW1 和距东河 $13 \mathrm{~km}$ 的 GW2 处地下水的 $\delta^{18} \mathrm{O}$ 为 $-9.84 \% \pm 0.00 \%$; 各样点位于河岸带, 因此 所采集的地下水 $\delta^{18} \mathrm{O}$ 波动较大, 且与河水的 $\delta^{18} \mathrm{O}$ 较 为接近; 远离河道的 $\mathrm{GW} 1$ 和 $\mathrm{GW} 2$ 处地下水的 $\delta^{18} \mathrm{O}$
较为稳定, 且低于样点处(即河岸带)地下水的 $\delta^{18} \mathrm{O}$ 。

沿土壤剖面, 土壤水的 $\delta^{18} \mathrm{O}$ 表现为从上到下贫 化的特点, 即表层土壤水同位素富集程度较高, 深 层土壤水同位素富集程度较低, $\delta^{18} \mathrm{O}$ 最高可达 $7.62 \%$ ，最低为 $-11.77 \%$ (图3)。样点 $\mathrm{E} 3$ 处沿土壤剖 面土壤水的 $\delta^{18} \mathrm{O}$ 变化较小, 表层为 $-4.66 \%$, 富集程 度较其他样点偏低, 与该处土壤接受河水漫溢补给 有关。沿土壤剖面土壤水的 $\delta^{18} \mathrm{O}$ 变化存在明显转折 点, 转折点以上, $\delta^{18} \mathrm{O}$ 从富集到贫化, 变化较大; 转 折点以下, $\delta^{18} \mathrm{O}$ 相对较为稳定, 在小幅范围内波动。

各样点所采集胡杨木质部水分的 $\delta^{18} \mathrm{O}$ 为 $-7.30 \%$ o $\pm 0.08 \%$, 最小值为 $-8.22 \%$, 最大值为 $-6.57 \%$; 多枝柽柳木质部水分的 $\delta^{18} \mathrm{O}$ 为 $-8.58 \% \pm$ $0.08 \%$, 最小值为 $-9.27 \%$, 最大值为 $-7.56 \%$ (图3)。

\section{2 植物吸收水分的主要土壤层位}

植物吸收水分的主要土壤层位采用氧同位素 直接对比法得出。图3中与胡杨和多枝柽柳木质部水 分的 $\delta^{18} \mathrm{O}$ 较为接近的土壤层范围, 即为胡杨和多枝 柽柳的主要吸水层位(表3)。植物主要吸水层位的下 边界为饱和土壤含水层的上边界, 因各样点处的地 下水位埋深而异。植物主要吸水层位的上边界平均 为 $100 \mathrm{~cm}$ 埋深处, 但各样点有所不同: 样点 $\mathrm{E} 3$ 的上 边界明显较其他样点浅, 主要是因该样点位于河漫 滩, 漫溢河水的补给作用远大于蒸发富集作用对浅 层土壤水 $\delta^{18} \mathrm{O}$ 的影响; 样点 $\mathrm{W} 2$ 的上边界明显较其 他样点深, 东河沿岸植物吸水层位上边界较西河沿 岸浅, 东河中游沿岸(E2)较东河上游沿岸(E1)浅, 东河下游沿岸E6处的上边界明显深于样点E4和E5。 植物吸水层位可能受地下水位波动、土壤物理特 性、河水侧向补给的渗透系数以及河水漫溢补给等 的影响。

\section{3 植物的补给水源}

该研究区植物可能的补给水源包括降水、河水 与地下水。深层土壤受河水侧渗补给和地下水垂向 补给, 而降水主要补给表层土壤, 且补给的土壤层 范围取决于降水入渗的深度。

样点 $\mathrm{E} 5$ 土壤体积含水量与降水数据表明: 在 降水开始后, $2 \mathrm{~cm}$ 埋深的土壤含水量最先开始升高, $4 \mathrm{~cm}$ 和10 $\mathrm{cm}$ 埋深土壤含水量升高稍有延迟, 且峰 值较低; $20 \mathrm{~cm}$ 埋深的土壤含水量仅在降水末期略有 上升; $40 \mathrm{~cm}$ 埋深的土壤含水量保持稳定(图4)。由此 说明, 降水入渗仅补给 $0-20 \mathrm{~cm}$ 埋深范围内的土层; 


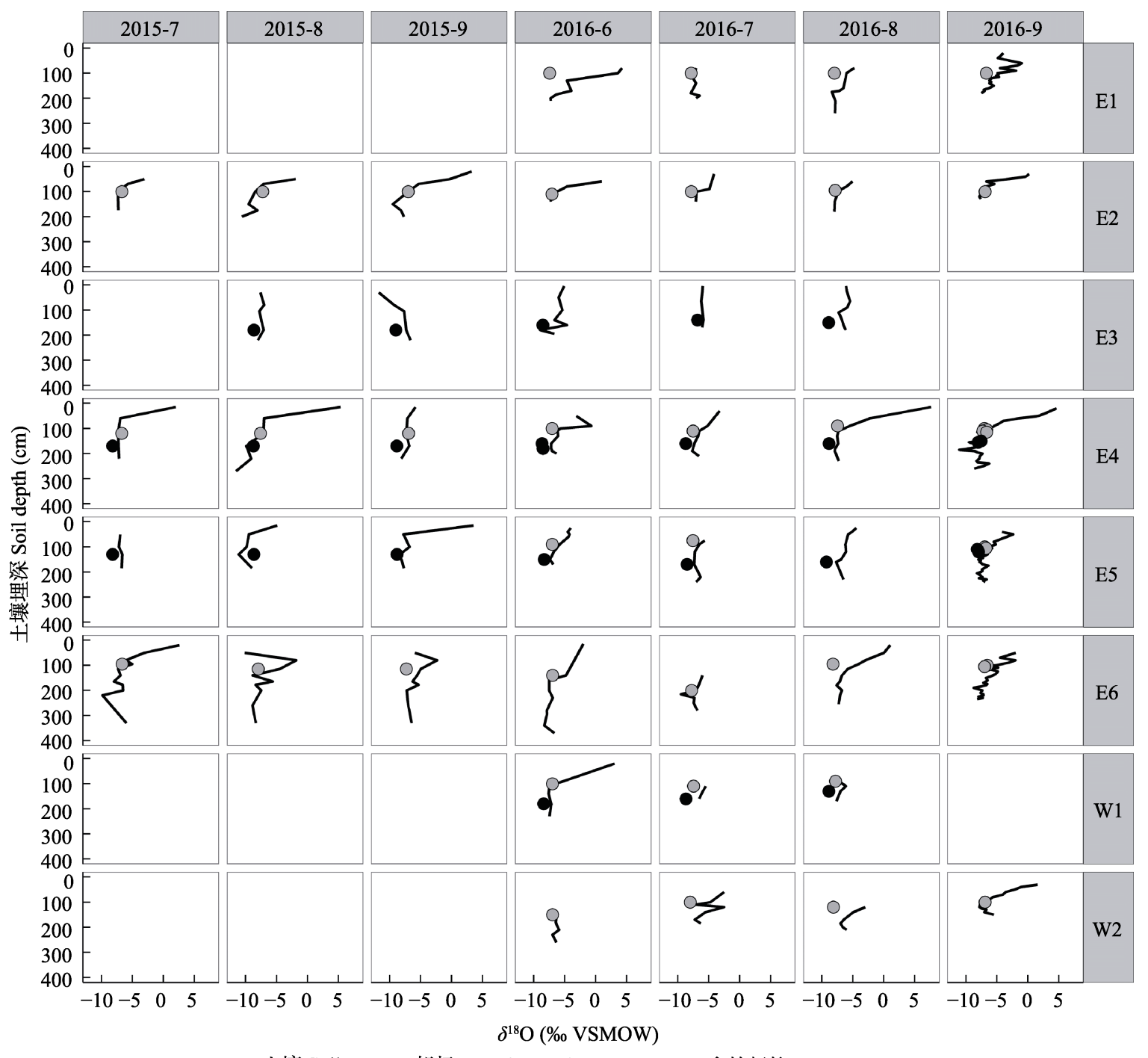

一 土壤 Soil ○ 胡杨 Populus euphratica

多枝柽柳 Tamarix ramosissima

图3 各样点土壤植物木质部水分的氧稳定同位素比率 $\left(\delta^{18} \mathrm{O}\right)$ 。各样点地理坐标见图1。VSMOW, 维也纳标准平均海水。

Fig. 3 The stable oxygen isotope ratio $\left(\delta^{18} \mathrm{O}\right)$ of soil moisture and plant xylem water at each sampling site. The coordinates of each sampling site are the same as in Fig.1. "VSMOW" is the abbreviation of "Vienna standard mean ocean water".

表3 各样点胡杨和多枝柽柳的主要吸水层位

Table 3 Dominant soil depths of root water uptake by Populus euphratica and Tamarix ramosissima at each sampling site

\begin{tabular}{|c|c|c|c|c|c|c|c|}
\hline \multirow{2}{*}{$\begin{array}{l}\text { 样点 }^{1)} \\
\text { Sampling site }^{1)}\end{array}$} & \multicolumn{7}{|c|}{ 植物主要吸水层位 Dominant soil depths of root water uptake ${ }^{2)}(\mathrm{cm})$} \\
\hline & $2015-7$ & $2015-8$ & $2015-9$ & $2016-6$ & $2016-7$ & $2016-8$ & $2016-9$ \\
\hline E1 & 1 & 1 & 1 & $130-210$ & $80-200$ & $80-260$ & $120-180$ \\
\hline E2 & $100-175$ & $100-200$ & $70-200$ & $80-140$ & $90-140$ & $80-180$ & $80-130$ \\
\hline E3 & & $30-220$ & $80-220$ & $50-195$ & $5-170$ & $25-180$ & 1 \\
\hline E4 & $60-220$ & $60-270$ & $60-220$ & $100-200$ & $110-210$ & $110-230$ & $100-260$ \\
\hline E5 & $50-185$ & $50-185$ & $50-185$ & $90-170$ & $75-240$ & $90-230$ & $110-240$ \\
\hline E6 & $80-330$ & $115-330$ & $115-330$ & $140-370$ & $140-280$ & $115-255$ & $100-235$ \\
\hline W1 & 1 & 1 & 1 & $100-230$ & $110-230$ & $90-?$ & 1 \\
\hline W2 & 1 & 1 & 1 & $150-260$ & $100-185$ & $170-210$ & $100-150$ \\
\hline
\end{tabular}

1) 各样点地理坐标见图1。2) “-”左侧数字为植物吸水层位的上边界, 右侧数字为植物吸水层位的下边界。“?” 表示因砾石过大, 土钻无法取样到饱和 土壤层。“””表示对应时段未采集样品，因此无统计结果。

1) The coordinates of each sampling site are the same as in Fig.1. 2) The values on the left side of the symbol "-_" represents the upper most depths of root water uptake, while the values on the right side of the signal "-_" represents the lower most depths of root water uptake. The symbol "?" indicates that the sampling did not reach the saturated soil depth due to the impeding of large gravel on soil sampler. "”" indicated that the samples were not taken at the corresponding time, and thus the corresponding results were missing.

www.plant-ecology.com 
各样点表层土壤质地类似(壤质砂土、粉壤土、砂壤 土, 表1), 因此研究区降水入渗最大深度在 $20 \mathrm{~cm}$ 范 围内; 除样点E3外, 降水入渗最大深度均未达到其 余样点处胡杨和多枝柽柳吸收水分的主要土壤层 位。因此对该研究区的胡杨和多枝柽柳而言, 降水 的补给可忽略不计, 而将河水与地下水作为胡杨和 多枝柽柳的主要补给水源, 也即河水与地下水对胡 杨和多枝柽柳的水分贡献率之和为 $100 \%$, 降水贡 献率记为 0 。

\section{4 补给水源对植物水分的贡献率}

利用IsoSource线性混合模型计算河水/地下水 对胡杨/多枝柽柳的水分贡献率, 首先需要确定输 入模型的河水/地下水的 $\delta^{18} \mathrm{O}$ 。考虑到河水补给作用 对河岸带地下水 $\delta^{18} \mathrm{O}$ 的影响, 以远离河道的 $\mathrm{GW} 1$ 和 $\mathrm{GW} 2$ 处地下水 $\delta^{18} \mathrm{O}$ 值-9.84\%o作为供给植物水分的 地下水 $\delta^{18} \mathrm{O}$ 值代入模型计算。河水的 $\delta^{18} \mathrm{O}$ 为 $-6.67 \%$ 土 $1.03 \%$ (平均值土标准误差), 分别以河水的“平均值” $(-6.67 \%) 、 “($ 平均值-标准误差)” $(-6.67 \% 0-1.03 \%)$ 和“平均值+标准误差” $(-6.67 \%$ o $1.03 \%$ o) 作为河水的 $\delta^{18} \mathrm{O}$ 值代入模型计算, 得到河水(和地下水)贡献率的 平均值以及最大值、最小值。

河水与地下水对胡杨和多枝柽柳的水分贡献率 结果如图5所示。河水对胡杨的水分贡献率表现为: 东河 $(70 \%)$ 略高于西河(64\%); 输水期(2015年7月和 2016年9月)河水对东、西河沿岸胡杨贡献率差距较 大, 分别为 $78 \%$ 和 $64 \%$; 非输水期差距较小, 分别为 $66 \%$ 和 $64 \%$ 。东河上(E1)、中 (E2)、下游(E3-E6)沿
岸河水对胡杨贡献率分别为 $68 \%$ 、69\%和 $71 \%$, 输水 期分别为 $85 \%$ 、 $82 \%$ 和 $86 \%$, 非输水期分别为 $62 \%$ 、 $64 \%$ 和 $64 \%$ 。西河中游沿岸(W1)未采集输水期胡杨 样品, 非输水期河水对胡杨贡献率为 $65 \%$; 西河下 游沿岸(W2)输水期和非输水期河水对胡杨贡献率 分别为 $79 \%$ 和 $58 \%$ 。

河水对多枝柽柳的水分贡献率表现为: 东河沿 岸和西河沿岸分别为 $34 \%$ 和 $32 \%$, 非输水期分别为 $30 \%$ 和 $32 \%$; 输水期东河沿岸河水对多枝柽柳贡 献率为 $47 \%$, 西河沿岸未采集到输水期多枝柽柳 样品。

地下水对胡杨的水分贡献率则表现为东河 $(30 \%)$ 略低于西河(36\%), 输水期(东河 $22 \%$ 和西河 $36 \%$ )低 于非输水期(东河 $34 \%$ 和西河 $36 \%$ )。地下水对东河与 西河沿岸多枝柽柳的贡献率则分别为 $66 \%$ 和 $68 \%$, 非输水期略高 $(70 \%$ 和 $68 \%$ ), 输水期略低(东河沿岸 为 $53 \%$, 西河沿岸未采集对应的多枝柽柳样品)。

河水和地下水对胡杨水分的平均贡献率分别 为 $68 \%$ 和 $32 \%$, 对多枝柽柳水分的平均贡献率分别 为 $35 \%$ 和 $65 \%$, 河水对胡杨的水分贡献率高于多枝 柽柳, 地下水对多枝柽柳的水分贡献率高于胡杨。 输水期(2015年7月、2016年9月)河水对胡杨的水分 贡献率高于平均值 $(84 \%)$, 对多枝柽柳的水分贡献 率也高于平均值(48\%); 河水对胡杨与多枝柽柳的 水分贡献率在输水期增大主要是由输水期间河水补 给作用较大所致。非输水期地下水对胡杨和多枝柽 柳的水分贡献率低于平均值(分别为 $37 \%$ 和 $70 \%$ )。

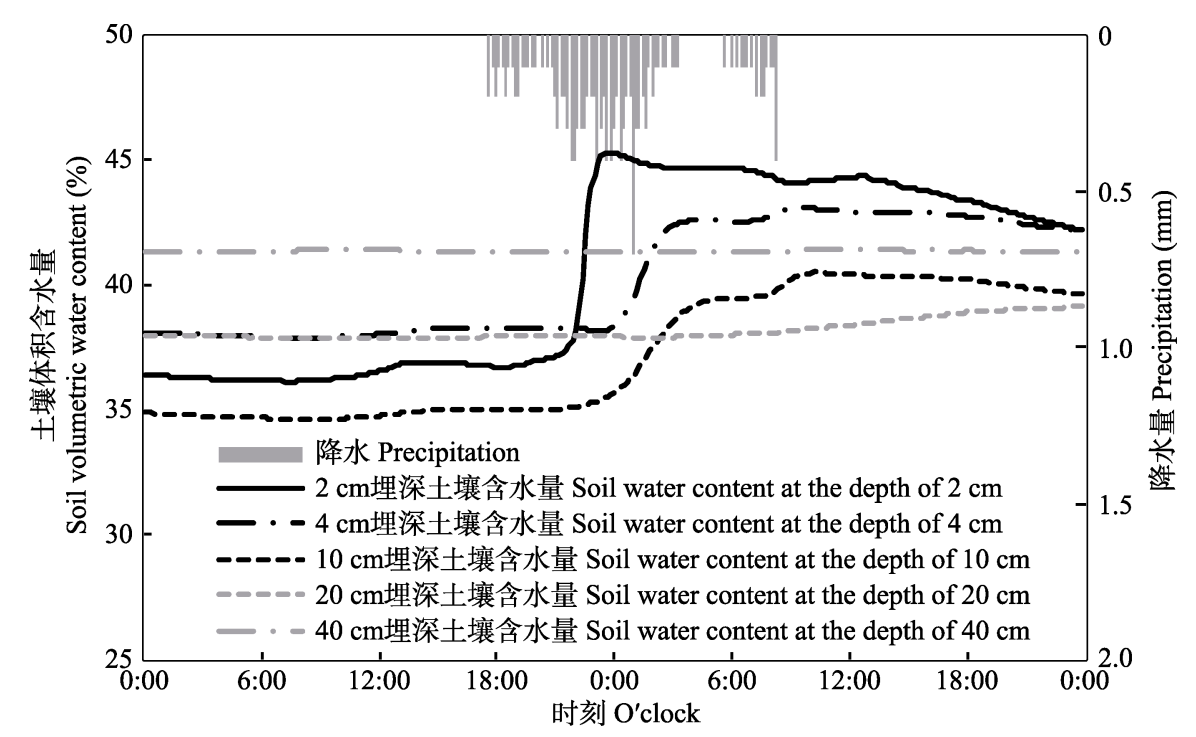

图4 样点E5 $\left(101.14^{\circ} \mathrm{E}, 42.00^{\circ} \mathrm{N}\right)$ 的 $10 \mathrm{~min}$ 降水与土壤含水量变化(2015-9-9-2015-9-10)。

Fig. 4 Dynamics of 10-min-gridded precipitation and soil water content at Site E5 (101.14 ${ }^{\circ}$ E, 42.00 ${ }^{\circ}$ N) (2015-9-9-2015-9-10). 

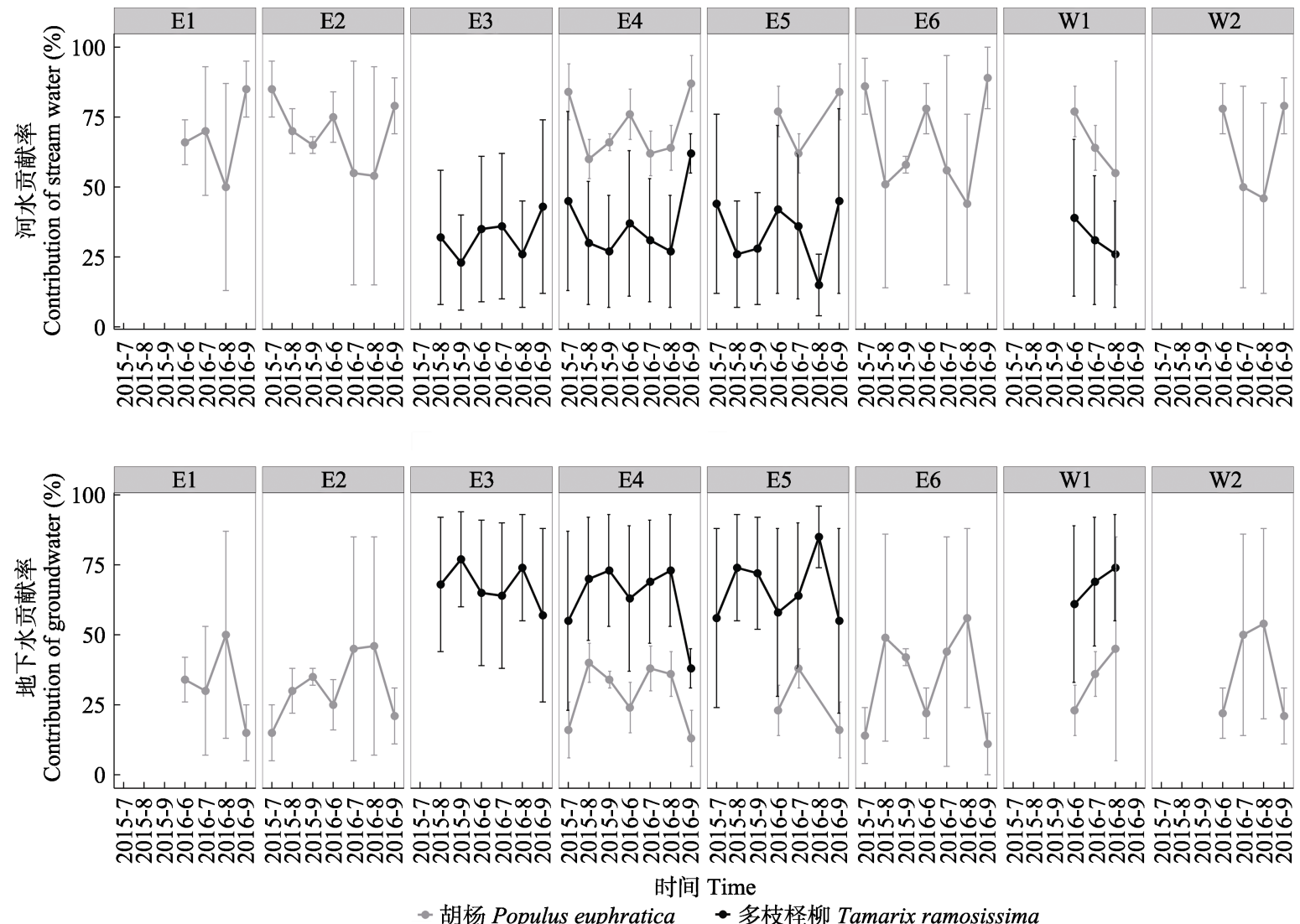

图5 河水与地下水对胡杨和多枝柽柳的贡献率。误差棒代表最小值和最大值。各样点地理坐标见图1。

Fig. 5 Proportional contribution (\%) of stream water and groundwater to the water sources of Populus euphratica and Tamarix ramosissima respectively. Bars indicate the minimum and maximum values. The coordinates of each sampling site are the same as in Fig.1.

\section{3 讨论}

\section{1 河水与地下水的交互作用}

河岸带地下水与河水的交互作用(Peng et al., 2015), 导致二者的 $\delta^{18} \mathrm{O}$ 值非常接近 (钱云平等, 2005), 很难将二者区分开来。在进行植物补给水源 对植物的水分贡献率计算时, 如直接将河岸带地下 水的 $\delta^{18} \mathrm{O}$ 值输入IsoSource模型进行补给水源贡献率 计算, 会将补给地下水的那部分河水对植物的水分 贡献率误计入地下水的贡献率中。本研究在计算植 物补给水源时, 以远离河道的地下水 $\delta^{18} \mathrm{O}$ 值代入模 型，是因为其相对河岸带地下水而言，受河水补给 影响较小, 且可与河水的 $\delta^{18} \mathrm{O}$ 区分开来, 从而定量 出河水与地下水的相对贡献率。基于氢氧同位素的 植物水分来源定量方法有待通过提高采样代表性和 测量精度以及优化模型来改进。

\section{2 植物水分来源的空间差异性影响因素}

胡杨和多枝柽柳吸收水分的主要土壤层位具 有显著的空间差异, 其中一个重要原因是河水的漫
溢补给作用。受漫溢河水补给的河岸带, 土壤浅层 含水量较高, 因此植物吸水层位相对较浅。如本研 究中, 东河下游沿岸样点 $\mathrm{E} 3$ 处, 植物主要吸水层位 上边界较其他样点浅; 尹力等(2012)在河水漫溢区 的研究也表明胡杨和多枝柽柳主要吸水层位最浅可 达 $40 \mathrm{~cm}$ 埋深。而本研究中未受河水漫溢补给的样点, 植物主要吸水层位相对较深, 陈小丽等(2014)的研 究也表明多枝柽柳吸水层位可达200-300 cm埋深。 此外, 未受河水漫溢补给的各样点处, 植物吸水层 位也存在较大差异, 可能是由地下水位波动、土壤 物理特性以及河水侧向补给的渗透系数不同所致。

河水/地下水对植物的平均水分贡献率的空间 差异并不显著, 可能是水源补给土壤水的范围, 仍 在植物根系吸水范围内所致; 但水源贡献率的值域 (即图5中最小值到最大值范围)较大, 主要是因为河 水 $\delta^{18} \mathrm{O}$ 值波动范围较大。因黑河水可能来自冰雪融 水、山区径流或地下径流，导致入额济纳三角洲的 河水 $\delta^{18} \mathrm{O}$ 值并不稳定(张应华和仵彦卿, 2007); 而补 给土壤水和地下水并被植物吸收利用的河水, 是多 
次河流来水的混合水源, 不能以单次河水采样结果 代表河水的 $\delta^{18} \mathrm{O}$ 。因此本研究在进行河水(与地下水) 贡献率的定量时，以河水 $\delta^{18} \mathrm{O}$ 的平均值和“平均值 \pm 标准误差” 输入模型, 得到水源贡献率的平均值和 值域。输入模型的河水 $\delta^{18} \mathrm{O}$ 取值不同, 也是造成前 人对河水和地下水贡献率的定量结果不一致的原因, 如陈小丽等(2014)得到地下水对多枝柽柳的水分贡 献率为 $16.4 \%$, 尹力等(2012)得到地下水对胡杨和多 枝柽柳的水分贡献率分别为 $34.9 \%$ 和 $21.2 \%$, 而褚建 民(2007)却定性给出胡杨主要利用地下水。

\section{3 植物水分利用对输水响应的季节性差异}

河水对胡杨和多枝柽柳的水分贡献率在输水 期增大, 非输水期减小, 但2016年6月初的采样在非 输水期进行, 河水对胡杨和多枝柽柳的水分贡献率 仍显著高于平均值(分别为 $75 \%$ 和 $38 \%$ ), 主要得益 于冬春季输水对土壤水的补给。冬春季输水补给土 壤水后被则存在土壤中, 而此时气温较低, 植物蒸 腾和裸土蒸发均相对较弱, 因此土壤有效含水量较 高; 受土壤物理特性限制, 地下水的垂向补给便相 对较弱, 贡献率也较河水低。但进入炎热夏季时, 如 没有生态输水, 河水的补给作用便相对较弱, 地下 水的垂向补给相对增强, 地下水的贡献率也随之增 大。由此说明, 冬春季输水有助于提高土壤有效含 水量; 夏季输水会导致蒸发耗散增大, 不利于河水 利用率的提高。

\section{4 结论}

本研究利用氧同位素直接对比法和IsoSource 线性混合模型, 分析计算了额济纳三角洲河岸带胡 杨、多枝柽柳的水分来源构成及其时空变化规律, 结果表明: 胡杨主要利用河水, 多枝柽柳主要利用 地下水, 但植物对水源的利用因河岸带地下水位波 动、土壤物理特性、河水侧渗补给及漫溢补给等, 存 在时空差异。河岸带河水/地下水交互作用导致河水 与地下水的 $\delta^{18} \mathrm{O}$ 值较为接近, 使得主要依靠河流来 水的极端干旱区河岸带植被的水分来源定量存在一 定的不确定性, 有待通过采样代表性和测试精度的 提高以及模型的优化以达到精准定量。生态输水方 案的实施不仅要考虑到黑河防汛抗旱和维护黑河下 游额济纳绿洲生态环境的需要, 还要从可持续发展 角度出发, 合理调控水资源配置, 以提高水资源利 用效率。
基金项目 国家自然科学基金面上项目(41571029、 41371059和41671023)。

致谢 感谢阿拉善乌海水文水资源勘测局为本研究 提供水文资料，感谢额济纳旗水务局提供采样支持, 感谢寒区旱区科学数据中心提供样点的降水和土壤 含水量数据, 感谢团队成员刘啸、王田野、李蓓在 野外采样中给予帮助。

\section{参考文献}

Chen XL, Chen YN, Chen YP (2014). Relationship among water use of different plants in Heihe River riparian forests. Chinese Journal of Eco-Agriculture, 22, 972-979. (in Chinese with English abstract) [陈小丽, 陈亚宁, 陈亚鹏 (2014). 黑河下游荒漠河岸林植物水分利用关系研究. 中国生态农业学报, 22, 972-979.]

Chu JM (2007). Studies on Selective Utilization of Water by Plants in Aridland Region. PhD dissertation, Chinese Academy of Forestry, Beijing. (in Chinese with English abstract) [禇建民 (2007). 干旱区植物的水分选择性利 用研究. 博士学位论文, 中国林业科学研究院, 北京.]

Du CY (2016). Simulation for Coupled Water-Vapor-Air-Heat Flow Transport in Vadose Zone and Estimation of Groundwater Evaporation in Arid Region - A Case Study of Ejina Delta. PhD dissertation, University of Chinese Academy of Sciences, Beijing. (in Chinese with English abstract) [杜朝阳 (2016). 干旱区包气带水-汽一气热耦 合模拟及潜水蒸发估算一以额济纳三角洲为例. 博士 学位论文, 中国科学院大学, 北京.]

Ehleringer J, Dawson T (1992). Water uptake by plants: Perspectives from stable isotope composition. Plant, Cell \& Environment, 15, 1073-1082.

Ehleringer JR, Phillips SL, Schuster WS, Sandquist DR (1991). Differential utilization of summer rains by desert plants. Oecologia, 88, 430-434.

Gong GL, Chen H, Duan DY (2011). Comparison of the methods using stable hydrogen and oxygen isotope to distinguish the water source of Nitraria tangutorum. Acta Ecologica Sinica, 31, 7533-7541. (in Chinese with English abstract) [巩国丽, 陈辉, 段德玉 (2011). 利用稳定 氢氧同位素定量区分白刺水分来源的方法比较. 生态 学报, 31, 7533-7541.]

Huxman TE, Smith MD, Fay PA, Knapp AK, Shaw MR, Loik ME, Smith SD, Tissue DT, Zak JC, Weltzin JF (2004). Convergence across biomes to a common rain-use efficiency. Nature, 429, 651-654.

Li X, Cheng G, Liu S, Xiao Q, Ma M, Jin R, Che T, Liu Q, Wang W, Qi Y (2013). Heihe watershed allied telemetry experimental research (HiWATER): Scientific objectives and experimental design. Bulletin of the American 
Meteorological Society, 94, 1145-1160.

Liu SM, Xu ZW, Wang WZ, Jia ZZ, Zhu MJ, Bai J, Wang JM (2011). A comparison of eddy-covariance and large aperture scintillometer measurements with respect to the energy balance closure problem. Hydrology and Earth System Sciences, 15, 1291-1306.

Meng XJ, Wen XF, Zhang XY, Han JJ, Sun XM, Li XB (2012). Potential impacts of organic contaminant on $\delta^{18} \mathrm{O}$ and $\delta \mathrm{D}$ in leaf and xylem water detected by isotope ratio infrared spectroscopy. Chinese Journal of Eco-Agriculture, 20, 1359-1365. (in Chinese with English abstract) [孟宪菁, 温学发, 张心昱, 韩佳音, 孙晓敏, 李晓波 (2012). 有 机物对红外光谱技术测定植物叶片和茎秆水 $\delta^{18} \mathrm{O}$ 和 $\delta \mathrm{D}$ 的影响. 中国生态农业学报, 20, 1359-1365.]

Peng XM, Xiao SC, Cheng GD, Xiao HL, Tian QY, Zhang QB (2015). Human activity impacts on the stem radial growth of Populus euphratica riparian forests in China's Ejina Oasis, using tree-ring analysis. Trees, 31, 379-392.

Qian YP, Lin XU, Qin DJ, Wang L (2005). Study on groundwater of the Ejina Basin at the lower reaches of the Heihe River using isotopes. Arid Land Geography, 28, 574-580. (in Chinese with English abstract) [钱云平, 林学钰, 秦大 军, 王玲 (2005). 应用同位素研究黑河下游额济纳盆地 地下水. 干旱区地理, 2005, 28, 574-580.]

Schachtschneider K, February EC (2010). The relationship between fog, floods, groundwater and tree growth along the lower Kuiseb River in the hyperarid Namib. Journal of Arid Environments, 74, 1632-1637.

Si JH, Feng Q, Xi HY, Yu TF, Li W (2013). Determination of critical period and requirement of ecological water demanded in the Ejina Oasis in lower reaches of the Heihe River. Journal of Desert Research, 33, 560-567. (in Chinese with English abstract) [司建华, 冯起, 席海洋, 鱼腾 飞, 李炜 (2013). 黑河下游额济纳绿洲生态需水关键期 及需水量. 中国沙漠, 33, 560-567.]

Snyder KA, Williams DG (2000). Water sources used by riparian trees varies among stream types on the San Pedro River, Arizona. Agricultural and Forest Meteorology, 105, 227-240.

Wang P, Yu J, Zhang Y, Fu G, Min L, Ao F (2011). Impacts of environmental flow controls on the water table and groundwater chemistry in the Ejina Delta, northwestern China. Environmental Earth Sciences, 64, 15-24.

Wang P, Yu J, Zhang Y, Liu C (2013). Groundwater recharge and hydrogeochemical evolution in the Ejina Basin, northwest China. Journal of Hydrology, 476, 72-86.

Wei Y, Fang J, Zhao X, Zhang R, Li S (2012). Isotopic model estimate of relative contribution of potential water pools to water uptake of Pinus sylvestris var. mongolica in Horqin Sandy Land. Journal of Resources and Ecology, 3, 308315.

Xing X, Chen H, Zhu JJ, Chen TT (2014). Water sources of five dominant desert plant species in Nuomuhong area of Qaidam Basin. Acta Ecologica Sinica, 34, 6277-6286. (in Chinese with English abstract) [邢星, 陈辉, 朱建佳, 陈 同同 (2014). 柴达木盆地诺木洪地区5种优势荒漠物水 分来源. 生态学报, 34, 6277-6286.]

Yin L, Zhao LJ, Ruan YF, Xiao HL, Cheng GD, Zhou MX, Wang F, Li CZ (2012). Study of the replenishment sources of typical ecosystems water and dominant plant water in the lower reaches of the Heihe, China. Journal of Glaciology \& Geocryology, 34, 1478-1486. (in Chinese with English abstract) [尹力, 赵良菊, 阮云峰, 肖洪浪, 程国 栋, 周茅先, 王芳, 李彩芝 (2012). 黑河下游典型生态 系统水分补给源及优势植物水分来源研究. 冰川冻土, 34, 1478-1486.]

Zhang YC, Yu JJ, Qiao MY, Yang HW (2011). Effects of eco-water transfer on changes of vegetation in the lower Heihe River Basin. Journal of Hydraulic Engineering, 42, 757-765. (in Chinese with English abstract) [张一驰, 于 静洁, 乔茂云, 杨宏伟 (2011). 黑河流域生态输水对下 游植被变化影响研究. 水利学报, 42, 757-765.]

Zhang YH, Wu YQ (2007). Variation of $\delta^{18} \mathrm{O}$ in water in Heihe River Basin. Advances in Water Science, 18, 864-870. (in Chinese with English abstract) [张应华, 仵彦卿 (2007). 黑河流域不同水体中 $\delta^{18} \mathrm{O}$ 的变化. 水科学进展, 18,864 870.]

Zhao LJ, Xiao HL, Cheng GD, Song YX, Zhao L, Li CZ, Yang Q (2008). A preliminary study of water sources of riparian plants in the lower reaches of the Heihe Basin. Acta Geoscientica Sinica, 29, 709-718. (in Chinese with English abstract) [赵良菊, 肖洪浪, 程国栋, 宋耀选, 赵亮, 李 彩芝, 杨秋 (2008). 黑河下游河岸林植物水分来源初步 研究. 地球学报, 29, 709-718.]

Zhu JT, Yu JJ, Wang P, Wang ZY (2011). Quantitative classification and analysis of relationships between plant communities and their groundwater environment in the Ejina Desert Oasis of China. Chinese Journal of Plant Ecology, 35, 480-489. (in Chinese with English abstract) [朱军涛, 于静洁, 王平, 王志勇 (2011). 额济纳荒漠绿 洲植物群落的数量分类及其与地下水环境的关系分析. 植物生态学报, 35, 480-489.]

责任编委: 陈世苹 责任编辑: 王 蒇 